\title{
Microbial abundance and community in subsurface flow constructed wetland microcosms: role of plant presence
}

Qian Wang, Huijun Xie, Huu Hao Ngo, Wenshan Guo, Jian Zhang, Cui Liu, Shuang Liang, Zhen Hu, Zhongchen Yang and Congcong Zhao

Q. Wang, J. Zhang, S. Liang, Z. Hu, Z. Yang, C. Zhao: Shandong Key Laboratory of Water Pollution Control and Resource Reuse, School of Environmental Science and Engineering, Shandong University, Jinan 250100, China

H. Xie: Environmental Research Institute, Shandong University, Jinan 250100, China

H. H. Ngo, W. Guo: School of Civil and Environmental Engineering, University of Technology Sydney, Broadway, Ultimo, NSW 2007, Australia

C. Liu: Department of Mathematics and Statistics, Texas Tech University, Broadway and Boston, Lubbock, TX 79409-1042, USA

\begin{abstract}
In this research, the role of plants in improving microorganism growth conditions in subsurface flow constructed wetland $(\mathrm{CW})$ microcosms was determined. In particular, microbial abundance and community were investigated during summer and winter in Phragmites australis-planted CW microcosms (PA) and unplanted CW microcosms (control, CT). Results revealed that the removal efficiencies of pollutants and microbial community structure varied in winter with variable microbial abundance. During summer, PA comprised more dominant phyla (e.g., Proteobacteria, Actinobacteria, and Bacteroidetes), whereas CT contained more Cyanobacteria and photosynthetic bacteria. During winter, the abundance of Proteobacteria was $>40 \%$ in PA but dramatically decreased in CT. Moreover, Cyanobacteria and photosynthetic bacterial dominance in CT decreased. In both seasons, bacteria were more abundant in root surfaces than in sand. Plant presence positively affected microbial abundance and community. The potential removal ability of $\mathrm{CT}$, in which Cyanobacteria and photosynthetic bacteria were abundant during summer, was more significantly affected by temperature reduction than that of PA with plant presence.
\end{abstract}

\section{Keywords}

Constructed wetland, summer, winter, microbial abundance, microbial community 


\section{Introduction}

Constructed wetlands (CWs) are inexpensive, easy to operate, consume low energy, and can be applied for treating various wastewaters (Zhi and Ji 2012). CWs have been applied to numerous wastewater treatment processes over the last 4 decades since their first application in Germany in the 1960s. CWs have been established as a means of treating domestic wastewaters globally (Bilgin et al. 2014). CW systems usually fall into two categories, namely, subsurface flow systems (SSF CWs) and free water surface flow system (SF CWs) (Dan et al. 2011). Designed with land saving and efficient wetland technology, SSF CWs have been successfully and widely applied in China and Europe (Perfler et al. 1999; Zhang et al. 2009; Wu et al.2011a).

The pollutant removal efficiencies in SSF CWs depend on oxidation-reduction conditions (Kadlec et al. 2000), which have been demonstrated for removing contaminants, such as organic contaminants and ammonium via microbial oxidation (García et al. 2005; Wiessner et al. 2005). However, the oxygen in SSF CWs is mainly eliminated via microbial oxidation from influent (Wen et al. 2010). Oxygen diffusion through water is approximately $10^{4}-10^{6}$ times slower than that through air (Drew et al. 1979). Oxygen in SSF CWs can be obtained much faster from plants by internal transfer via the air spaces in plants (Armstrong 1978; Brix 1997). Therefore, the strong oxygen gradients within SSF CWs have been linked to the presence of plants (Shelef et al. 2013).

Microorganisms are considered responsible for the transformation and mineralization of pollutants in CWs; plants, one of the primary $\mathrm{CW}$ components, have a strong functional linkage with microbial biomass, diversity, and activity (Collins et al. 2004; Truu et al. 2009). Plants can provide microorganisms with attachment surfaces, plant-media oxygen, and carbon sources from root leakage (Brix 1997; Stottmeister et al. 2003; Faulwetter et al. 2013). Consequently, organic pollutants have high removal efficiency via several bacterial groups that favor oxygen (Braeckevelt et al. 2007). Plant roots improve oxygen conditions, thereby supporting the aerobic processes in CWs at flooded conditions (Sundberg et al. 2007). However, some studies posited that plants do not statistically affect the microbial community structure (Ahn et al. 2007; Baptista et al. 2008). Thus, the effects of plants on microbial groups, particularly in SSF CWs, must be further explored.

Plant growth and physiological status are extremely diverse in different seasons, so

the effects of plant presence on the microbial community at different seasons must be investigated. In this study, we aimed to investigate the role of plant presence in CWs by 
comparatively evaluating microbial abundance and community during summer and winter, during which distinct differences in plant growth and physiological status were observed. CWs were either planted with Phragmites australis (PA) or left unplanted (CT, control). Quantitative polymerase chain reaction (qPCR) and 454 high-throughput pyrosequencing were conducted to analyze the $16 \mathrm{~S}$ rRNA gene of total bacteria for elucidating the role of plants in CWs from a microbial aspect.

\section{Materials and methods}

Site description and experimental design

The studied CWs are located in the Shan Dong Normal University in Jinan, China. This area has a warm monsoon climate, cold and dry winter, and hot and wet summer and is characterized by a mean annual precipitation of $670.7 \mathrm{~mm}$ and average temperature of $14.3^{\circ} \mathrm{C}$. Microcosm wetland systems were designed and constructed in SSF style for domestic wastewater treatment on 12 March 2013. The microcosms comprised six individual polyvinyl chloride columns. Three of the microcosms were planted with P. australis, whereas the remaining three were unplanted for the control (CT). Each column was $48 \mathrm{~cm}$ in depth and $30 \mathrm{~cm}$ in diameter. The outlet at the bottom of the column was filled with a three-layer filter with $19 \mathrm{~cm}$ deep gravel $(5-7 \mathrm{~cm}$ in diameter) at the bottom, $15 \mathrm{~cm}$ deep gravel $(2-4 \mathrm{~cm}$ in diameter) in the middle, and $10 \mathrm{~cm}$ deep washed sand (particle size $<2 \mathrm{~mm}$ ) on top. A perforated pipe ( $30 \mathrm{~mm}$ in diameter) was inserted into the center of the system to measure the physical and chemical parameters in situ. P. australis was transplanted from the Nansi Lake in Shan Dong Province. After 10 days of cultivation, healthy plants of similar sizes were transplanted into the microcosms (PA treatment). Plant density was 15 rhizomes/cell. The microcosms were placed in a greenhouse with a glass roof, and the temperature control system was closed to obtain natural temperature variations at different seasons.

The microcosms were fed with synthetic wastewater to primarily simulate the treated domestic wastewater (Table 1). Sequencing fill-and-draw batch mode was used to operate the $\mathrm{CW}$ microcosms. The wetlands were saturated with wastewater for treatment, drained after an experiment cycle, and immediately refilled with synthetic wastewater again after drainage at the start of the next cycle. A total of $4 \mathrm{~L}$ of influent was manually filled into the microcosms to maintain the water level below the sand surface. Each microcosm was manually drained through a valve at the bottom after one cycle. Evapotranspiration loss was estimated and 
compensated by adding deionized water during the experiment. Each wetland microcosm was operated in a batch with a hydraulic retention time of 7 days. Before the experiments, the wetlands had been pre-cultured for 4 months. Recent studies showed that microbial communities can be stabilized after a period of 75-100 days during the start-up process of $\mathrm{CW}$ microcosms. After 4 months, the bacterial community in the microcosms was believed to be stable (Truu et al. 2009; Weber and Legge 2011).

Table 1 Characteristics of influents from the wetland microcosm units (mean $\pm \mathrm{SD}, n=10$ )

\begin{tabular}{lllll}
\hline \multicolumn{2}{l}{ Influents composition } & Parameter & Summer & Winter \\
\hline Sucrose & $50 \mathrm{mg} / \mathrm{L}$ & $\mathrm{COD}(\mathrm{mg} / \mathrm{L})$ & $60.3 \pm 0.54$ & $60.84 \pm 0.79$ \\
$\left.\mathbf{N H}_{4}\right)_{2} \mathbf{S O}_{4}$ & $56.29 \mathrm{mg} / \mathrm{L}$ & $\mathrm{NH}_{4}-\mathrm{N}(\mathrm{mg} / \mathrm{L})$ & $15.65 \pm 0.62$ & $15.60 \pm 1.06$ \\
$\mathbf{K H}_{\mathbf{2}} \mathbf{P O}_{4}$ & $17.5 \mathrm{mg} / \mathrm{L}$ & $\mathrm{NO}_{3}-\mathrm{N}(\mathrm{mg} / \mathrm{L})$ & $10.18 \pm 0.32$ & $12.18 \pm 1.03$ \\
$\mathbf{M g S O}_{4}$ & $10 \mathrm{mg} / \mathrm{L}$ & $\mathrm{NO}_{2}-\mathrm{N}(\mathrm{mg} / \mathrm{L})$ & $0.012 \pm 0.00$ & $0.003 \pm 0.00$ \\
$\mathbf{F e S O}_{4}$ & $10 \mathrm{mg} / \mathrm{L}$ & $\mathrm{DO}(\mathrm{mg} / \mathrm{L})$ & $6.91 \pm 1.21$ & $12.24 \pm 1.37$ \\
$\mathbf{C a C l}_{\mathbf{2}}$ & $10 \mathrm{mg} / \mathrm{L}$ & Temperature $\left({ }^{\circ} \mathrm{C}\right)$ & $26.90 \pm 3.2$ & $4.60 \pm 2.4$ \\
\hline
\end{tabular}

Water sampling and analysis

Both influent and effluent were sampled every 7 days to evaluate the changes in organic components and nitrogen during summer (from 12 July to 9 August) and winter (9 December to 6 January). The water samples were analyzed in the laboratory for chemical oxygen demand (COD) and ammonium $\left(\mathrm{NH}_{4}{ }^{+}-\mathrm{N}\right)$. All parameters were determined according to the standard methods (APHA 2001). COD was measured with a HACH DR 2800TM spectrophotometer (USA) using the potassium dichromate method. The $\mathrm{NH}_{4}{ }^{+}-\mathrm{N}$ concentrations were determined with a UV-vis spectrophotometer (Shimadzu Instrument Co. Ltd., UV-2450, Japan) using Nessler's reagent colorimetry. Meanwhile, dissolved oxygen (DO) was gauged in situ using DO electrodes (HQ30d 53LEDTM, HACH, USA).

\section{Microbial sampling}

Sand and root samples for DNA extraction were obtained from each microcosm on 2 July, 23 July, and 9 August during summer, and on 16 December, 28 December, and 6 January during winter. Initially, the water in each microcosm was completely drained through the bottom valve. Sand from a depth of 5 to $10 \mathrm{~cm}$ was collected at five different locations (four corners and the center of the microcosms) (Calheiros et al. 2010; Wu et al. 2013) in each parallel and 
then mixed into a composite sample. The sand samples from the three parallel microcosms were subsequently combined into a composite sample before DNA extraction. For root samples, the plants were first removed from the column. Residue was then removed from the plants by shaking them in a container with sterile water. The roots (approximately $0.5-1 \mathrm{~mm}$ in diameter) near the root tips (Faulwetter et al. 2013) were aseptically excised from the plants. The sand and root samples were stored in 5-mL aseptic Eppendorf tubes, which were immediately placed on ice and then stored at $-80{ }^{\circ} \mathrm{C}$ before microbial analysis.

\section{Genomic DNA extraction}

DNA was extracted from the previously frozen biomass using a MOBIO PowerSand ${ }^{\mathrm{TM}}$ DNA kit (MOBIO, Carlsbad, CA) according to the manufacturer's instructions. DNA yields were measured with an ND-1000 UV-Vis spectrophotometer (NanoDrop Technologies, Wilmington, DE, USA), and integrity was evaluated via $1.5 \%$ of agarose gel electrophoresis. DNA products were then stored at $-20^{\circ} \mathrm{C}$ before analysis.

\section{qPCR analysis}

A Roche LC-480 real-time PCR system $(\mathrm{CH})$ was used to quantify the $16 \mathrm{~S}$ rRNA genes with the primer Eub341F/Eub534R (Muyzer et al. 1993) and SYBR ${ }^{\circledR}$ Premix Ex Taq ${ }^{\mathrm{TM}}$ (TaKaRa, Japan). Template DNA was diluted 100 times before amplification (Di et al. 2010). The total amount of the reaction mixture was $20 \mu \mathrm{L}$, which comprised $10.0 \mu \mathrm{L}$ of $\mathrm{SYBR}{ }^{\circledR}$ Premix Ex Taq $^{\mathrm{TM}}, 2 \mu \mathrm{L}$ of template DNA (1-10 ng), $0.4 \mu \mathrm{L}$ of forward and reverse primers $(10 \mu \mathrm{M})$, and $7.2 \mu \mathrm{L}$ of nuclease-free water. The qPCR cycling conditions were as follows: $30 \mathrm{~s}$ at $95^{\circ} \mathrm{C}$ and 40 cycles of $10 \mathrm{~s}$ at $95^{\circ} \mathrm{C}, 15 \mathrm{~s}$ at $60{ }^{\circ} \mathrm{C}$, and $20 \mathrm{~s}$ at $72{ }^{\circ} \mathrm{C}$. The abundance of the targeted genes in each sample was determined by Abs Quant/2nd Derivative Max from Roche LC-480 Install on the basis of parallel qPCR of different dilutions of the standards. The threshold cycles $(\mathrm{Ct})$ obtained in each PCR run were compared with those of the known standard DNA concentrations. Standard curves were obtained following the procedure described by Di et al. (2010).

\section{Pyrosequencing and data analysis}

Numerous studies have realized the pyrosequencing of 16S rRNA V3 hypervariable regions of the bacteria in CWs for quantifying bacterial populations and characterizing microbial 
community diversity using PCR-DGGE technique or 454 sequencing platform with wastewater treatment (Zhong et al. 2014; Faulwetter et al.2013; Dong and Reddy 2010). In the current study, the 16S rDNA hypervariable V3 region was amplified through PCR with the universal bacterial primers 341f (Watanabe et al. 2001) and -518r (Muyzer et al. 1993). The prepared DNA samples were sequenced on the 454 Genome Sequencer FLX Titanium platform according to the procedure detailed by Gong et al. (2013). Pyrosequencing was performed in the Chinese National Human Genome Sequencing Center (Shanghai), and calculations were performed by Mothur analysis (Schloss et al. 2009). The sequences were assigned to phylogenetic taxonomy using the Ribosomal Database Project classifier (Wang et al. 2007).

\section{Results}

\section{Performance of wetlands}

The influent characteristics are described in Table 1. The average temperature and DO concentration in summer were $26.90 \pm 3.2^{\circ} \mathrm{C}$ and $6.91 \pm 1.21 \mathrm{mg} / \mathrm{L}$, respectively (Table 1 ). COD removal was measured based on the data collected from 12 July to 9 August. The overall COD removal efficiency was $70.62 \pm 3.83 \%$ in PA and $67.92 \pm 6.4 \%$ in CT (Fig. 1). The difference in COD removal between the planted and unplanted $\mathrm{CW}$ units during summer was not remarkable.

The removal and transformation mechanisms of nitrogen in CWs are mainly via assimilation into biomass and sediment, followed by removal through microbial nitrification and denitrification (Jamieson et al. 2003). Reinhardt et al. (2006) discovered that denitrification contributes $94 \%$ to nitrogen removal but only $6 \%$ in sediments. In the current research, after 4 months, the sorption of ammonia by gravel/sand in the columns was observed, but it was not the primary means for removing ammonia. Therefore, the sorption of ammonia by gravel/sand was not determined in this study. Figure 1 shows that high $\mathrm{NH}_{4}{ }^{+}-\mathrm{N}$ removals were achieved in both types of wetlands $(91.02 \pm 1.36 \%$ for PA and $88.81 \pm 3.14 \%$ for $\mathrm{CT})$.

During winter, the temperature in the influent decreased to $4.60 \pm 2.4^{\circ} \mathrm{C}$, whereas the DO concentration increased to $12.24 \pm 1.37 \mathrm{mg} / \mathrm{L}$. In this season, the differences between the planted and unplanted units were apparent $(P<0.05)$ at low temperature. The COD reductions in PA and CT were 42.09 and $23.22 \%$, respectively. Between December and 
January, the removals of $\mathrm{NH}_{4}{ }^{+}-\mathrm{N}$ were 70.38 and $49.72 \%$ in the PA and CT units, respectively.

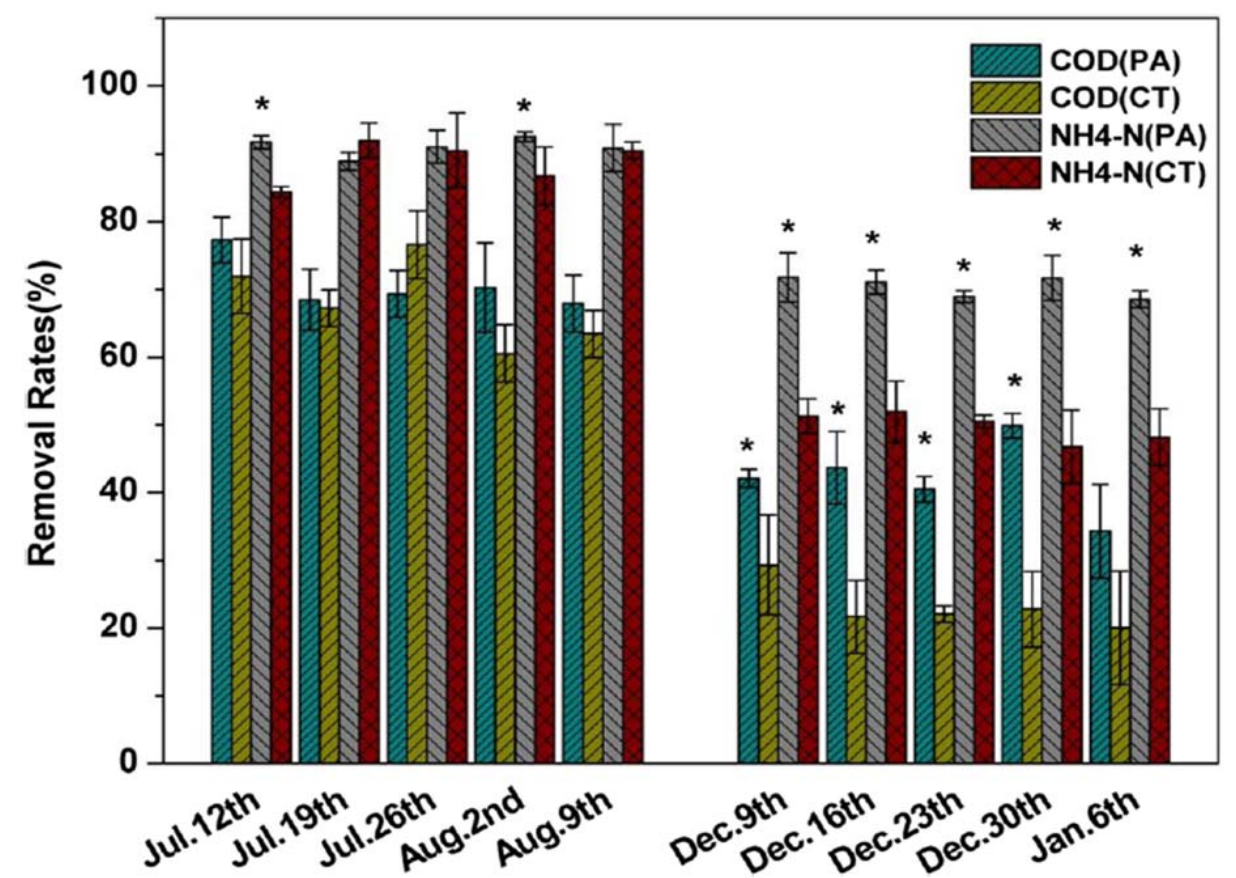

Fig. 1 The COD and $\mathrm{NH}_{4}{ }^{+}-\mathrm{N}$ removal rates in PA and CT during summer (July 12 to August 9) and winter (December 9 to January 6). Error bars represent standard error $(n=3)$. $* P<0.05$ (statistical analysis was performed by use of a SPSS statistics program)

Given that the $\mathrm{COD}$ and $\mathrm{NH}_{4}{ }^{+}-\mathrm{N}$ removals in all wetlands decreased with declining temperature, the performance of wetlands was affected by the season. Meanwhile, considering that the reduction in $\mathrm{NH}_{4}{ }^{+}-\mathrm{N}$ removal efficiency during winter was significantly lower in PA than that in $\mathrm{CT}$, the seasonal effect on $\mathrm{NH}_{4}{ }^{+}-\mathrm{N}$ removal was more significant in unplanted wetlands.

\section{Microbial abundance}

We detected microbial abundance using qPCR with the gene of $16 \mathrm{~S}$ rRNA at different seasons. Paired sample $t$ test was performed to evaluate the statistical differences of microbial abundance between PA and CT at different seasons (shown in Supplementary Material Table 3). The abundance of the total bacteria (including those in plant roots) in PA and CT is demonstrated in Fig. 2. During summer, the amount of bacteria in plant roots 
$\left(1.85 \times 10^{6}\right.$ copies/g roots) was significantly higher than that in sand. However, the differences between PA $\left(1.54 \times 10^{5}\right.$ copies/g sand $)$ and CT sand $\left(1.48 \times 10^{5}\right.$ copies $/ g$ sand $)$ were not obvious ( $P=0.846$, Supplementary Material Table 3 ). During winter, the abundance of the total bacteria was $2.09 \times 10^{5}$ copies/g on the roots of the plants and was obviously higher than that in sand. In the same season, the copies of 16S rRNA in sand were higher in $\mathrm{PA}\left(7.60 \times 10^{4}\right.$ copies $/ \mathrm{g}$ sand $)$ than those in CT $\left(2.76 \times 10^{4} \mathrm{copies} / \mathrm{g}\right.$ sand, $P=0.024$, Supplementary Material Table 3). For the two types of wetlands, the total bacterial abundance on the root surfaces and sands decreased from summer to winter.

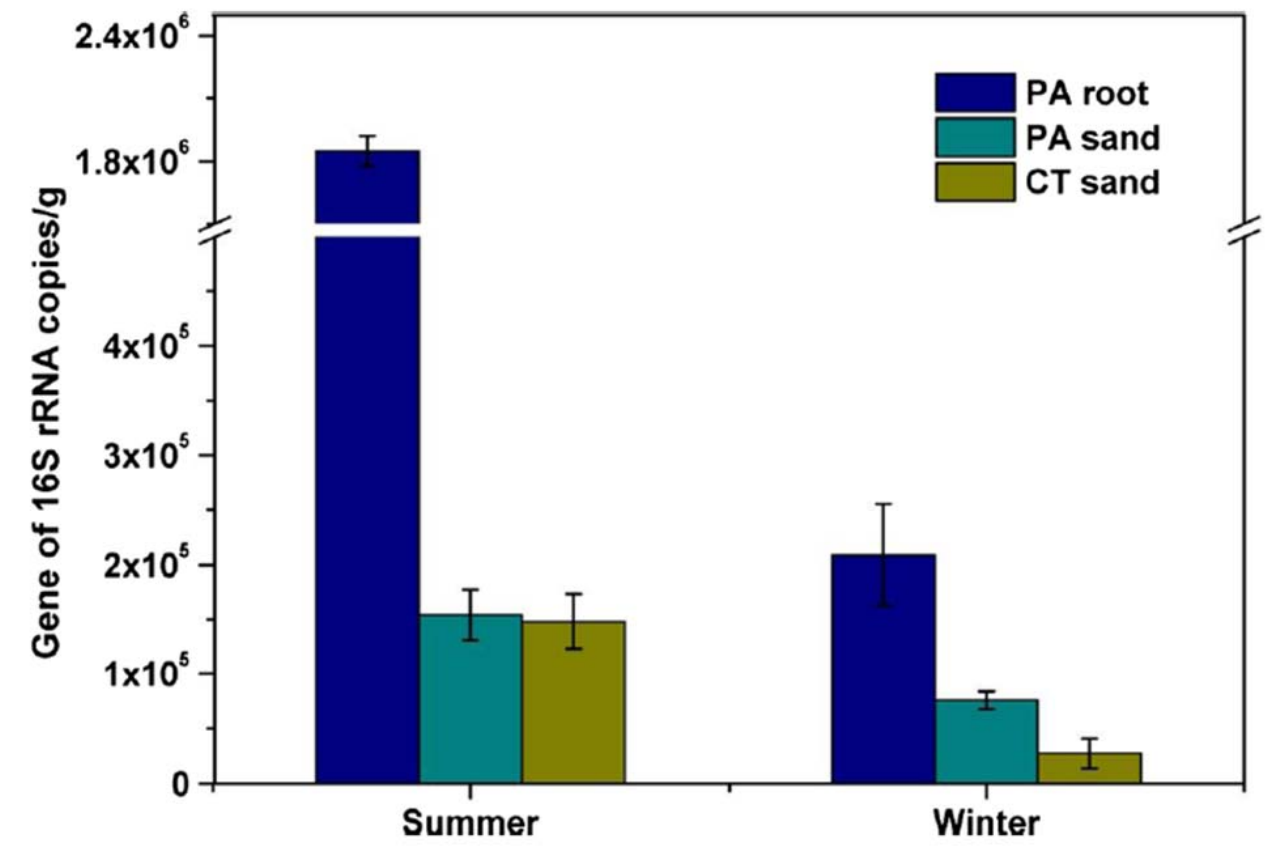

Fig. 2 The abundances of total bacteria by gene of 16S rRNA copies per gram on roots of plant and in sands of PA and CT in summer and winter. Error bars represent standard error $(n=3)$

\section{Microbial community}

Microbial communities can be stabilized after 75-100 days during the start-up process of CW microcosms (Truu et al. 2009; Weber and Legge 2011). The establishment of denitrifying bacteria populations within 75 days and ammonium- and nitrite-oxidizing bacteria within 95 days has been reported in reactors with sand filters (Pell and Nyberg 1989). After a 4month study period, we sampled the sand and roots in the microcosms to detect the microbial community using pyrosequencing. 
The microbial composition structure of the total bacteria in wetlands is shown in Fig. 3. A total of 25 phyla were identified during summer, in which Proteobacteria, Actinobacteria, Bacteroidetes, and Cyanobacteria comprised the largest proportion. Table 2 describes the relative sequence abundance of different phyla in wetlands and presents the overall increase or decrease of the microbial composition from summer to winter. During summer, the order of prominent phyla in planted wetlands was Proteobacteria > Actinobacteria $>$ Bacteroidetes $>$ Cyanobacteria (Table 2). This finding differed from that in unplanted wetlands. The prominent phyla in unplanted wetlands was in the order of Proteobacteria $>$ Cyanobacteria $>$ Actinobacteria $>$ Bacteroidetes. PA generally contained more Proteobacteria, Actinobacteria, and Bacteroidetes than CT. However, the relative sequence abundance of Cyanobacteria was significantly higher in CT (29.62\%) than that in PA $(7.26 \%)$.
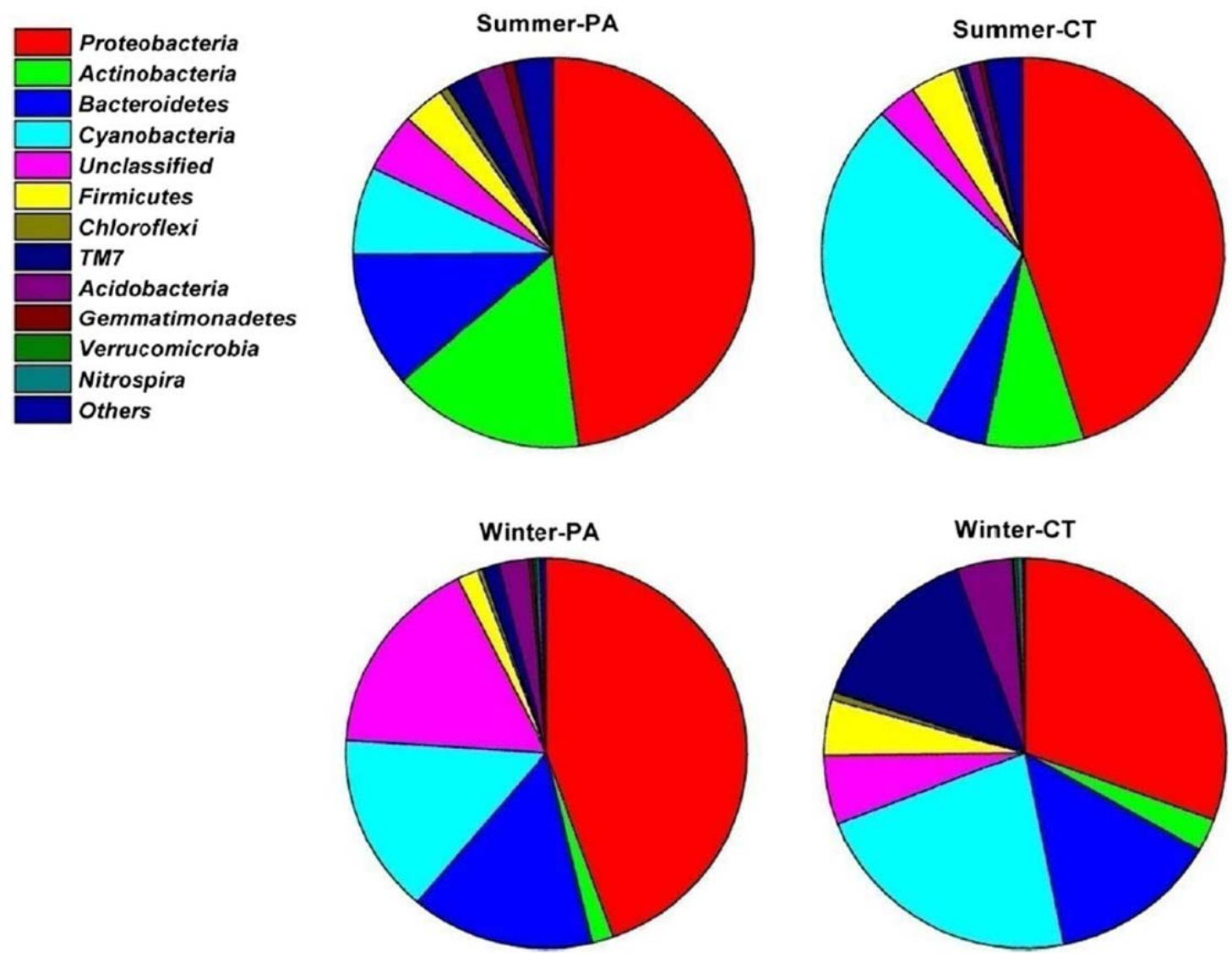

Fig. 3 The relative abundance of total bacterial V3 tags obtained by pyrosequencing from PA and CT in summer and winter, by phylum, and profiled the overall structure of bacteria communities 
Table 2 The relative abundance (\%) of total bacterial V3 tags for PA and CT in summer and winter, by phylum, and profiled the overall increase or decrease of the microbial compositions from summer to winter

\begin{tabular}{lllllll}
\hline Phylum & \multicolumn{2}{l}{ Summer } & \multicolumn{3}{c}{ Winter } & \multicolumn{2}{c}{ Discrepancy $^{\mathbf{a}}$} \\
\cline { 2 - 7 } Proteobacteria & PA & CT & PA & CT & PA & CT \\
Actinobacteria & 47.96 & 45.08 & 44.60 & 30.61 & -3.36 & -14.47 \\
Bacteroidetes & 15.60 & 7.85 & 1.71 & 2.67 & -13.89 & -5.18 \\
Cyanobacteria & 11.36 & 5.04 & 14.85 & 13.65 & 3.49 & 8.61 \\
Unclassified & 7.26 & 29.62 & 14.86 & 22.11 & 7.60 & -7.51 \\
Firmicutes & 4.87 & 3.17 & 16.68 & 5.73 & 11.81 & 2.56 \\
Chloroflexi & 3.36 & 3.81 & 1.69 & 4.60 & -1.67 & 0.79 \\
TM7 & 0.71 & 0.36 & 0.38 & 0.65 & -0.33 & 0.29 \\
Acidobacteria & 2.51 & 0.67 & 1.36 & 14.59 & -1.15 & 13.92 \\
Gemmatimonadetes & 2.27 & 0.98 & 2.42 & 4.37 & 0.15 & 3.40 \\
Verrucomicrobia & 0.89 & 0.41 & 0.33 & 0.12 & -0.56 & -0.29 \\
Nitrospira & 0.06 & 0.07 & 0.21 & 0.27 & 0.15 & 0.20 \\
Others & 0.03 & 0.04 & 0.41 & 0.44 & 0.38 & 0.40 \\
\hline
\end{tabular}

${ }^{\mathrm{a}}$ The results of discrepancy were calculated by relative sequence abundance of winter minus that of summer

Nineteen phyla were identified during winter. Proteobacteria was the predominant phylum in all wetlands. The relative sequence abundance of Proteobacteria was higher than $40 \%$ in planted wetlands, whereas their abundance in unplanted units decreased significantly (Table 2). Cyanobacteria in unplanted units also exhibited a similar trend.

The abundance of different classes within Proteobacteria is presented in Fig. 4 and Table 3. The results showed that the wetlands with plants had abundant bacterial composition in all four classes during summer and winter. For the unplanted units, alpha-Proteobacteria decreased from summer to winter (Table 3). Meanwhile, the photosynthetic bacteria Rhodobacter and Catellibacterium of Rhodobacteraceae and Roseomonas of Acetobacteraceae (black spots in the red square in Fig. 4) remarkably decreased during winter but were highly abundant during summer. 

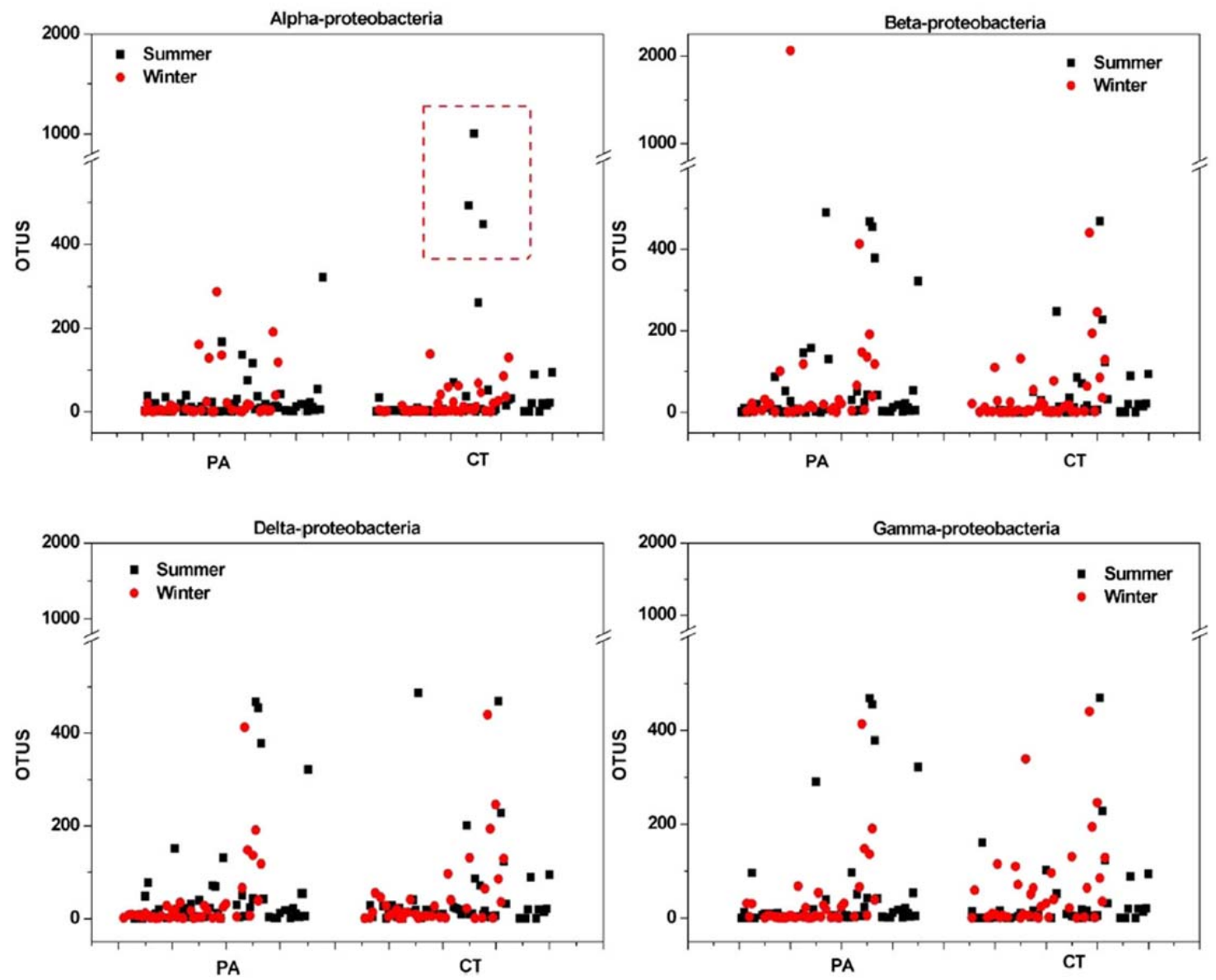

Fig. 4 The OTUs of alpha, beta, delta, and gamma-Proteobacteria for PA and CT in summer and winter

Table 3 The relative sequence abundance (\%) of Proteobacteria for PA and CT in summer and winter, by class, and profiled the overall increase or decrease of the microbial compositions from summer to winter

\begin{tabular}{lllllll}
\hline Class & \multicolumn{2}{c}{ Summer } & \multicolumn{3}{c}{ Winter } & \multicolumn{2}{c}{ Discrepancy } \\
\cline { 2 - 7 } & PA & CT & PA & CT & PA & CT \\
Alpha & 11.75 & 21.78 & 10.50 & 6.37 & -1.35 & -15.41 \\
Beta & 22.34 & 11.26 & 27.89 & 11.64 & 10.78 & 0.38 \\
Delta & 7.08 & 8.08 & 2.57 & 4.49 & -8.27 & -3.59 \\
Epsilon & 0.02 & 0.02 & 0.00 & 0.01 & -0.59 & -0.01 \\
Gamma & 5.69 & 3.43 & 2.19 & 6.92 & -2.64 & 3.49 \\
Unclassified & 1.09 & 0.56 & 1.45 & 1.33 & 1.06 & 0.77 \\
Total & 47.96 & 45.08 & 44.60 & 30.61 & -3.36 & -14.47 \\
\hline
\end{tabular}




\section{Discussion}

\section{Role of plant presence during summer}

The temperature during summer is conducive to plant and microorganism growth (Huang et al. 2013). Moreover, the roots of plants can provide microbes with large attachment surfaces (Brix 1997; Vymazal2011). Our previous study reported that plants directly absorb nutrients at warm temperature (Wu et al.2011a). In the present study, plants could positively influence the microbial community, but their effects on microbial abundance in sand were not evident in summer.

The bacterial quantity on root surfaces was ten times higher than that in sand. Previous studies determined that plant roots can support large surfaces for bacterial attachment, as well as release oxygen and exudates to provide root-attached microbes with a suitable environment for their survival (Münch et al. 2005; Ruiz-Rueda et al. 2009; Yang et al. 2001). However, the microbial abundance in sand demonstrated a marginal difference for planted and unplanted units $(P=0.846$, shown in Supplementary Material Table 3$)$. The results indicated that plants positively affected microbial abundance on root surfaces during summer but had relatively less effects on microbial abundance in sand. Oxygen released from plant roots can affect the abundance of microbial bacteria, and bacterial communities are grouped according to a gradient of oxygen concentration (Armstrong and Armstrong 1990; Luederitz et al. 2001; Ansola et al. 2014). During root respiration, oxygen from plant media is consumed or transported back into the atmosphere; the remaining oxygen is leaked from the root region to the rhizosphere through a process called radial oxygen loss (Brix and Schierup 1990; Tanaka et al. 2007). However, oxygen can be absorbed again by roots to satisfy the demands of root respiration. In this study, we discovered that root respiration was high during summer when plants were actively growing (Supplementary Material Table 1). The high root respiration rate on the oxygen content in the rhizosphere decreased the oxygen support from plant-media transfer. Reports claim that microbial abundance is related to pollutant removal (Ge et al. 2011). In the current research, the marginal difference in microbial abundance between PA and CT indicated the lack of advantageous effects of plant on microbial abundance in sand for pollutant removal compared with the unplanted ones during summer.

The effect of plants on the microbial community was also investigated. The method of 454 high-throughput sequencing was employed to elucidate the diversity and composition structure of microorganisms (Ye et al.2011; Zhang et al.2011). The total numbers of 
operational taxonomic units (OTUs) obtained using a Chao estimator were 3056 and 2451 in PA and CT, respectively (Supplementary Material Table 2), with infinite sampling at $3 \%$ distance. The Shannon diversity index was used to characterize the diversity, abundance, and uniformity of the species present (Ma et al. 2013). The results revealed that the Shannon index of PA (6.30) was higher than that of CT (5.08) (Supplementary Material Table 2). Higher Chao estimator and Shannon diversity index inferred that more microbial species diversity and abundance were present in planted microcosms with uniform distribution than those under unplanted conditions. The CW ecosystem function is the sum of all processes provided by a given ecosystem (Hooper et al. 2005). Given that some studies suggested that diversity positively affects the ecosystem functions, the higher bacterial diversity in planted wetland may indicate more ecosystem functions beneficial for the removal processes (Ansola et al.2014). Moreover, the dominant phyla in wetlands (Proteobacteria, Actinobacteria, and Bacteroidetes) were more abundant in planted wetlands than that in unplanted ones. The Proteobacteria phylum displays a remarkably high level of bacterial metabolic diversity related to global carbon, nitrogen, and sulfur cycling, such as Methylophilales, Nitrosomonadales, and Desulfuromonadales, which play important roles in pollutant removal (Kersters et al. 2006; Ansola et al. 2014). The aforementioned findings implied that the planted wetland microcosms could maintain a stable and satisfactory removal efficiency with abundant ecosystem functions and high levels of metabolic bacterial groups in summer.

However, the COD and ammonia removal efficiency of unplanted microcosms was high in summer. During this period, the unplanted microcosms also contained a large proportion of Proteobacteria (45.08 \%), but this proportion was lower than that in the planted ones $(47.96 \%)$. This result revealed that the unplanted microcosms also had good pollutant removal potential. The second large proportion in the unplanted microcosms was the Cyanobacteria. The presence of Cyanobacteria can enhance the transformation of pollutants by bacteria rather than individual microorganisms (Subashchandrabose et al.2011). Moreover, Rhodobacter and Catellibacterium of Rhodobacteraceae and Roseomonas of Acetobacteraceae were remarkably abundant during summer, among which Rhodobacteraceae are photosynthetic bacteria (Garrity et al. 2006) and exhibit significant potential for wastewater treatment (Barbosa et al. 2001; Ike et al. 1997; Sasaki et al. 2005). Cyanobacteria and photosynthetic bacteria provide the pollutant-degrading heterotrophic bacteria with the key electron acceptor (oxygen); this relationship further supported the photoautotrophic growth of their partners by providing 
them with carbon dioxide and other stimulatory agents (Subashchandrabose et al. 2011). The photosynthetic bacteria, heterotrophic bacteria, and Cyanobacteria might maintain a stable ecological relationship with one another in the absence of plants. Therefore, the unplanted wetland microcosms demonstrated potential removal ability during summer when the microcosms contained a large proportion of Proteobacteria, as well as an appropriate amount of Cyanobacteria and photosynthetic bacteria. The presence of photosynthetic organisms depends on the amount of available sunlight. This research demonstrated that the plants did not provide complete shade, and some areas of sand were exposed. Some photosynthetic bacteria were also observed in the planted microcosms, but their proportions were lower than the unplanted ones without plant shading.

\section{Role of plant presence during winter}

During winter, low temperature is the primary factor that negatively impacts the activity of plants and microbial bacteria (Huang et al. 2013). Direct absorption is also weakened during the dormancy period of plants throughout the cold season (Harper et al. 1987). In the present study, the effects of temperature on the removal efficiency in unplanted wetlands were more apparent than those in planted wetlands, which was consistent with other studies. Taylor et al. (2011) determined that COD removal decreases at low temperatures in controls but displays limited seasonal variations in planted microcosms. Moreover, Allen et al. (2002) found that the differences in $\mathrm{CW}$ performance among plant species were remarkably greater at $4{ }^{\circ} \mathrm{C}$ during plant dormancy than those at $24{ }^{\circ} \mathrm{C}$ during the plant growing season. However, previous studies primarily analyzed the pollutant removal efficiency but did not specify any data on the bacterial groups. In the present study, we examined the pollutant removal, microbial abundance, and microbial community and found differences between the planted and unplanted wetlands during winter in terms of their microbial abundance and microbial community.

Microbial abundance on root surfaces was higher than that in the sand, and the amount of bacteria in the sand of planted wetlands was higher than that of the unplanted ones $(P=0.024$, shown in Supplementary Material Table 3$)$. The findings indicated that microbial abundance was positively associated with the presence of plants during winter. The total number of OTUs estimated according to the Chao estimator was 2599 and 3156 for PA and $\mathrm{CT}$, respectively, thereby suggesting that microbial abundance was not superior in planted wetlands. The Shannon index of PA (4.77) was much lower than that of CT (5.61) 
(Supplementary Material Table 2), which implied that the OTUs in the planted community were no more uniformly distributed than those under the unplanted conditions during winter. However, the dominant phylum Proteobacteria remained at a high level in planted units (44.6\%) but markedly decreased in unplanted units $(30.61 \%)$. We also observed that the amount of released oxygen and root respiration decreased during winter (Supplementary Material Table 1). Considering that the plant roots remained active even when the aboveground was dormant, more oxygen and other exudates (not detected in this work) from plants might be obtained during winter than during summer because of the decrease in the demands of the plants (Stein and Hook 2005). Previous studies reported that the high oxygen and root exudates in wetlands provide satisfactory conditions for microbial processes (Jensen et al. 2007; Wu et al. 2011b). Our previous work demonstrated that the plant-media oxygen transfer significantly affects microbial abundance and activity during winter, thereby enhancing pollutant removal compared with the microcosms with removed plants (Wang et al. 2014). In the present study, we inferred that the presence of plants during winter could also increase microbial abundance and affect the microbial community through the resources derived from the roots to maintain stable removal efficiency.

The removal efficiency in the unplanted units significantly decreased compared with that in the planted ones because of low microbial abundance, which corresponded with the effluent removal efficiency (Truu et al.2009). The proportion of Proteobacteria, particularly Rhodobacteraceae of alpha-Proteobacteria, in unplanted microcosms decreased in winter. Similarly, Cyanobacteria decreased during this period. Hence, the stable ecological relationship among photosynthetic bacteria, heterotrophic bacteria, and Cyanobacteria was destabilized by temperature reduction. Overall, the removal efficiency in unplanted wetland microcosms could not maintain the same level as that in planted wetland microcosms during the cold season.

\section{Conclusion}

For low-concentration domestic wastewater treatment, no obvious differences were determined between planted and unplanted wetland microcosms during summer. By contrast, the differences were great in winter, during which the removal efficiency of both wetland microcosms (PA and CT) decreased. The presence of plants positively affected both microbial abundance and community even in cold weather when the aboveground parts of the plants were dormant. The unplanted wetlands also exhibited their potential removal ability 
during summer when the microcosms contained a large proportion of Proteobacteria and an appropriate amount of Cyanobacteria and photosynthetic bacteria. However, the removal ability of unplanted wetlands could be greatly affected by temperature reduction compared with that of the planted ones.

\section{Acknowledgments}

We gratefully acknowledge financial support by the National Science Foundation of China (21007032 and 21307078), Shandong Provincial Natural Science Foundation, China (2009ZRB019Y9), and the Independent Innovation Foundation of Shandong University (2012JC029 and 2014JC023).

\section{References}

Ahn C, Gillevet P, Sikaroodi M (2007) Molecular characterization of microbial communities in treatment microcosm wetlands as influenced by macrophytes and phosphorus loading. Ecol Indic 7:852-863

Allen WC, Hook PB, Biederman JA, Stein OR (2002) Temperature and wetland plant species effects on wastewater treatment and root zone oxidation. J Environ Qual 31:1010-1016

Ansola G, Arroyo P, Sáenz de Miera LE (2014) Characterisation of the soil bacterial community structure and composition of natural and constructed wetlands. Sci Total Environ 473:63-71

APHA (2001) In: Frances, P.D., Keith, I. (Eds.), Compendium of Methods for the Microbiological Examination of Foods. Washington, DC

Armstrong W (1978) Root aeration in the wetland condition. Plant life Anaerobic Environ $1: 197$

Armstrong J, Armstrong W (1990) Light-enhanced convective throughflow increases oxygenation in rhizomes and rhizosphere of Phragmites australis (Cav.) Trin. ex Steud. New Phytol 114:121-128

Baptista JC, Davenport RJ, Donnelly T, Curtis TP (2008) The microbial diversity of laboratory-scale wetlands appears to be randomly assembled. Water Res 42:3182-3190

BarbosaMJ, Rocha J, Tramper J,Wijffels RH (2001) Acetate as a carbon source for hydrogen production by photosynthetic bacteria. J Biotechnol 85:25-33 
Bilgin M, Şimşek İ, Tulun Ş (2014) Treatment of domestic wastewater using a lab-scale activated sludge/vertical flow subsurface constructed wetlands by using Cyperus alternifolius Ecol Eng 70:362-365

Braeckevelt M, Rokadia H, Imfeld G, Stelzer N, Paschke H, Kuschk P, Kästner M, Richnow H-H, Weber S (2007) Assessment of in situ biodegradation of monochlorobenzene in contaminated groundwater treated in a constructed wetland. Environ Pollut 148:428-437

Brix H (1997) Do macrophytes play a role in constructed treatment wetlands? Water Sci Technol 35:11-17

Brix H, Schierup H-H (1990) Soil oxygenation in constructed reed beds: the role of macrophyte and soil-atmosphere interface oxygen transport. Constructed wetlands in water pollution control, 53-66

Calheiros C, Teixeira A, Pires C, Franco A, Duque A, Crispim L, Moura S, Castro P (2010) Bacterial community dynamics in horizontal flow constructed wetlands with different plants for high salinity industrial wastewater polishing. Water Res 44:5032-5038

Collins B, McArthur JV, Sharitz RR (2004) Plant effects on microbial assemblages and remediation of acidic coal pile runoff in mesocosm treatment wetlands. Ecol Eng 23:107-115

Dan TH, Quang LN, Chiem NH, Brix H (2011) Treatment of high-strength wastewater in tropical constructed wetlands planted with Sesbania sesban: horizontal subsurface flow versus vertical downflow. Ecol Eng 37:711-720

Di HJ, Cameron KC, Shen JP,Winefield CS, O'CallaghanM, Bowatte S, He JZ (2010) Ammonia-oxidizing bacteria and archaea grow under contrasting soil nitrogen conditions. FEMSMicrobiol Ecol 72:386-394

Dong X, Reddy GB (2010) Soil bacterial communities in constructed wetlands treated with swine wastewater using PCR-DGGE technique. Bioresour Technol 101:1175-1182

Drew M, Jackson M, Giffard S (1979) Ethylene-promoted adventitious rooting and development of cortical air spaces (aerenchyma) in roots may be adaptive responses to flooding in Zea mays L. Planta 147: 83-88

Faulwetter JL, Burr MD, Parker AE, Stein OR, Camper AK (2013) Influence of season and plant species on the abundance and diversity of sulfate reducing bacteria and ammonia oxidizing bacteria in constructed wetland microcosms. Microb Ecol 65:111-127 
García J, Aguirre P, Barragán J, Mujeriego R, Matamoros V, Bayona JM (2005) Effect of key design parameters on the efficiency of horizontal subsurface flow constructed wetlands. Ecol Eng 25:405-418

Garrity G, Bell J, Lilburn T (2006) Rhodobacteraceae fam. nov. List of New Names and New Combinations Previously Effectively, but not Validly, Published, 1-6

Ge Y, Zhang C, Jiang Y, Yue C, Jiang Q, Min H, Fan H, Zeng Q, Chang J (2011) Soil microbial abundances and enzyme activities in different rhizospheres in an integrated vertical flow constructed wetland. CLEAN-Soil, Air, Water 39:206-211

Gong H-L, Shi Y, Zhou L, Wu C-P, Cao P-Y, Tao L, Xu C, Hou D-S, Wang Y-Z (2013) The composition of microbiome in larynx and the throat biodiversity between laryngeal squamous cell carcinoma patients and control population. PLoS One 8:e66476

Harper L, Langdale G, Giddens J (1987) Nitrogen cycling in a wheat crop: soil, plant, and aerial nitrogen transport. Agron J 79:965-973

Hooper D, Chapin Iii F, Ewel J, Hector A, Inchausti P, Lavorel S, Lawton J, Lodge D, Loreau M, Naeem S (2005) Effects of biodiversity on ecosystem functioning: a consensus of current knowledge. Ecol Monogr 75:3-35

Huang J, Cai W, Zhong Q, Wang S (2013) Influence of temperature on micro-environment, plant eco-physiology and nitrogen removal effect in subsurface flow constructed wetland. Ecol Eng 60:242-248

Ike A, Toda N, Tsuji N, Hirata K, Miyamoto K (1997) Hydrogen photoproduction from CO2fixing microalgal biomass: application of halotolerant photosynthetic bacteria. J Ferment Bioeng 84:606-609

Jamieson TS, Stratton GW, Gordon R, Madani A (2003) The use of aeration to enhance ammonia nitrogen removal in constructed wetlands. Can Biosyst Eng 45:1.9-1.14

Jensen SI, Kühl M, Priemé A (2007) Different bacterial communities associated with the roots and bulk sediment of the seagrass Zostera marina. FEMS Microbiol Ecol 62:108117

Kadlec RH, Knight RL, Vymazal J, Brix H, Cooper P, Haberl R (2000) Constructed wetlands for pollution control: processes, performance, design and operation. IWA scientific and technical report No.8. IWA specialist group on use of macrophytes in water pollution control. IWA Publishing; $155 \mathrm{pp}$ 
Kersters K, de Vos P, Gillis M, Swings J, Vandamme P, Stackebrandt E (2006) Introduction to the Proteobacteria. In: Dwarkin M, Falkow S, Rosenberg E, Schleifer KH, Stackebrandt E (eds) The prokaryotes, vol 5, 3rd edn. Springer, New York, pp 3-37

Luederitz V, Eckert E, Lange-Weber M, Lange A, Gersberg RM (2001) Nutrient removal efficiency and resource economics of vertical flow and horizontal flow constructed wetlands. Ecol Eng 18:157-171

Münch C, Kuschk P, Rske I (2005) Root stimulated nitrogen removal: only a local effect or important for water treatment? Water Sci Technol 51:185-192

Muyzer G, de Waal EC, Uitterlinden AG (1993) Profiling of complex microbial populations by denaturing gradient gel electrophoresis analysis of polymerase chain reactionamplified genes coding for 16S rRNA. Appl Environ Microbiol 59:695-700

PellM, Nyberg F (1989) Infiltration of wastewater in a newly started pilot sand-filter system: I. Reduction of organic matter and phosphorus. J Environ Qual 18:457-462

Perfler R, Laber J, Langergraber G, Haberl R (1999) Constructed wetlands for rehabilitation and reuse of surface waters in tropical and subtropical areas-first results from smallscale plots using vertical flow beds. Water Sci Technol 40:155-162

Reinhardt M, Mller B, Gchter R, Wehrli B (2006) Nitrogen removal in a small constructed wetland: an isotope mass balance approach. Environ Sci Technol 40:3313-3319

Ruiz-Rueda O, Hallin S, Bañeras L (2009) Structure and function of denitrifying and nitrifying bacterial communities in relation to the plant species in a constructed wetland. FEMS Microbiol Ecol 67: 308-319

Sasaki K, Watanabe M, Suda Y, Ishizuka A, Noparatnaraporn N (2005) Applications of photosynthetic bacteria for medical fields. J Bio Bioeng 100:481-488

Schloss PD,Westcott SL, Ryabin T, Hall JR, Hartmann M, Hollister EB, Lesniewski RA, Oakley BB, Parks DH, Robinson CJ (2009) Introducing mothur: open-source, platformindependent, community-supported software for describing and comparing microbial communities. Appl Environ Microbiol 75:7537-7541

Shelef O, Gross A, Rachmilevitch S (2013) Role of plants in a constructed wetland: current and new perspectives. Water 5:405-419 
Stein OR, Hook PB (2005) Temperature, plants, and oxygen: how does season affect constructed wetland performance? J Environ Sci Heal 40:1331-1342

Stottmeister U, Wießner A, Kuschk P, Kappelmeyer U, Kästner M, Bederski O, Müller R, Moormann H (2003) Effects of plants and microorganisms in constructed wetlands for wastewater treatment. Biotechnol Adv 22:93-117

Subashchandrabose SR, Ramakrishnan B, Megharaj M, Venkateswarlu K, Naidu R (2011) Consortia of cyanobacteria/microalgae and bacteria: biotechnological potential. Biotechnol Adv 29:896-907

Sundberg C, Stendahl JSK, Tonderski K, Lindgren P-E (2007) Overland flow systems for treatment of landfill leachates - potential nitrification and structure of the ammoniaoxidising bacterial community during a growing season. Soil Biol Biochem 39:127-138

Tanaka N, Yutani K, Aye T, Jinadasa K (2007) Effect of broken dead culms of Phragmites australis on radial oxygen loss in relation to radiation and temperature. Hydrobiologia $583: 165-172$

Taylor CR, Hook PB, Stein OR, Zabinski CA (2011) Seasonal effects of 19 plant species on COD removal in subsurface treatment wetland microcosms. Ecol Eng 37:703-710

Truu M, Juhanson J, Truu J (2009) Microbial biomass, activity and community composition in constructed wetlands. Sci Total Environ 407: 3958-3971

Vymazal J (2011) Plants used in constructed wetlands with horizontal subsurface flow: a review. Hydrobiol 674:133-156

Wang Q, Garrity GM, Tiedje JM, Cole JR (2007) Naive Bayesian classifier for rapid assignment of rRNA sequences into the new bacterial taxonomy. Appl Environ Microbiol 73:5261-5267

Wang Q, Xie H, Zhang J, Liang S, Ngo HH, GuoW, Liu C, Zhao CC, Li H (2014) Effect of plant harvesting on the performance of constructed wetlands during winter: radial oxygen loss and microbial characteristics.

Watanabe K, Kodama Y, Harayama S (2001) Design and evaluation of PCR primers to amplify bacterial $16 \mathrm{~S}$ ribosomal DNA fragments used for community fingerprinting. $\mathrm{J}$ Microbiol Methods 44:253-262 
Weber KP, Legge RL (2011) Dynamics in the bacterial community level physiological profiles and hydrological characteristics of constructed wetland mesocosms during startup. Ecol Eng 37:666-677

Wen Y, Chen Y, Zheng N, Yang D, Zhou Q (2010) Effects of plant biomass on nitrate removal and transformation of carbon sources in subsurface-flow constructed wetlands. Bioresour Technol 101: 7286-7292

Wießner A, Kappelmeyer U, Kuschk P, Kästner M (2005) Influence of the redox condition dynamics on the removal efficiency of a laboratory-scale constructed wetland. Water Res $39: 248-256$

Wu H, Zhang J, Li P, Zhang J, Xie H, Zhang B (2011a) Nutrient removal in constructed microcosm wetlands for treating polluted river water in northern China. Ecol Eng $37: 560-568$

Wu S, Zhang D, Austin D, Dong R, Pang C (2011b) Evaluation of a labscale tidal flow constructed wetland performance: oxygen transfer capacity, organic matter and ammonium removal. Ecol Eng 37: 1789-1795

Wu S-q, Chang J-j, Dai Y, Wu Z-b, Liang W (2013) Treatment performance and microorganism community structure of integrated vertical-flow constructed wetland plots for domestic wastewater.

Yang L, Chang H-T, HuangM-NL (2001) Nutrient removal in gravel-and soil-based wetland microcosms with and without vegetation. Ecol Eng 18:91-105

Ye L, Shao M-F, Zhang T, Tong AHY, Lok S (2011) Analysis of the bacterial community in a laboratory-scale nitrification reactor and a wastewater treatment plant by 454pyrosequencing.Water Res 45: 4390-4398

Zhang D, Gersberg RM, Keat TS (2009) Constructed wetlands in China. Ecol Eng 35:13671378

Zhang T, Shao M-F, Ye L (2011) 454 Pyrosequencing reveals bacterial diversity of activated sludge from14 sewage treatment plants. ISMEJ 6:1137-1147

Zhi W, Ji G (2012) Constructed wetlands, 1991-2011: a review of research development, current trends, and future directions. Sci Total Environ 441:19-27 
Zhong F,Wu J, Dai YR, Zhang ZH,Cheng SP, Zhang Q (2014) Bacterial community analysis by PCR-DGGE and 454-pyrosequencing of horizontal subsurface flow constructed wetlands with front aeration. Appl Microbiol Biotechnol, 1-14 